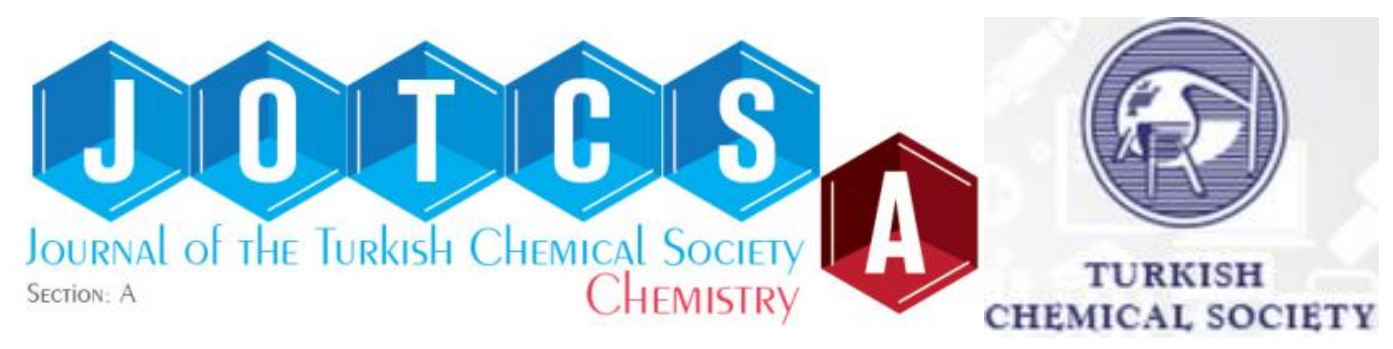

\title{
Syntheses and spectroscopic investigations of 2-pyridyl(N/N)spirocyclotriphosphazenes
}

\author{
Gamze Elmas $\triangle$ \\ Ankara University, 06100, Ankara, Turkey
}

\begin{abstract}
The $\mathrm{Cl}$ substitution reaction of $\mathrm{N}_{3} \mathrm{P}_{3} \mathrm{Cl}_{6}$ (1) with $N$-(2-pyridyl)-methyl- $N^{\prime}-$ methylpropane-1,3-diamine

afforded the partly substituted 2pyridyl(N/N)spirocyclotriphosphazene (3) (with a yield of 57\%) in dry THF. When the Cl replacement reactions of $\mathbf{2}$ carried out with excess pyrrolidine, morpholine, and 1,4-dioxa8-azaspiro[4,5]decane (DASD), the corresponding 2-pyridyl(N/N)spirotetrapyrrolidino (3a), tetramorpholino (3b) and tetra(1,4-dioxa-8-azaspiro[4,5]decano) (3c) cyclotriphosphazenes were prepared in moderate yields. The structures of four cyclotriphosphazene derivatives were elucidated by the elemental analyses, Fourier transform infrared (FTIR), heteronuclear mass spectrometry (ESI-MS), heteronuclear multiple-bond correlation (HMBC), single quantum coherence (HSQC), ${ }^{1} \mathrm{H},{ }^{13} \mathrm{C}$, and ${ }^{31} \mathrm{P}$ NMR techniques.
\end{abstract}

Keywords: 2-Pyridyl(N/N)spirocyclotriphosphazenes, Replacement reactions, Spectroscopy

Submitted: January 17 ,2018. Accepted: March 29, 2018.

Cite This: Elmas G. Syntheses and spectroscopic investigations of 2pyridyl(N/N)spirocyclotriphosphazenes. JOTCSA. 2018;5(2):621-34.

DOI: http://dx.doi.org/10.18596/jotcsa.379971.

*Corresponding author. E-mail: gegemen@ankara.edu.tr

Tel: $+9003122126720 / 1195$. 


\section{INTRODUCTION}

Cyclophosphazenes are inorganic heterocyclic ring systems consisting of a backbone that contains the repeating unit $\left[\mathrm{N}=\mathrm{PX}_{2}\right]_{\mathrm{n}}(\mathrm{n}=3,4,5, \ldots)$ with nitrogen and phosphorus atoms and two organic, inorganic and/or organometallic side groups (X), linked covalently to each phosphorus atom $(1,2)$. Hexachlorocyclotriphosphazene, $\mathrm{N}_{3} \mathrm{P}_{3} \mathrm{Cl}_{6}$, is the best-known starting compound used for the preparation of the new phosphazene derivatives in the field of phosphazene chemistry (3). Hence, its $\mathrm{Cl}$ substitution reactions with monodentate $(4,5)$ and bidentate reagents $(6,7)$ have been thoroughly examined for years on account of the formation of various structural isomers and stereoisomers. The replacement reactions of $\mathrm{N}_{3} \mathrm{P}_{3} \mathrm{Cl}_{6}$ with monoamines and diamines led to the formation of partly and fully substituted aminocyclotriphosphazenes (8). For instance, in the literature, there are many studies on the reactions of $\mathrm{N}_{3} \mathrm{P}_{3} \mathrm{Cl}_{6}$ with various $\mathrm{N} / \mathrm{N}$ donor typed difunctional ligands, e.g. containing 4-fluorobenzyl, ferrocenyl, and 4-nitrobenzyl pendant arms for the formation of the partly substituted (N/N)spirocyclotriphosphazenes (9-11). The fully substituted cyclophosphazenes are also obtained with the reactions of these products with excess monoamines (9-11).

On the other hand, the prepared cyclotriphosphazenes are used as liquid crystalline materials (12), ionic liquids (13), organic light emitting diodes (OLEDs) (14), photosensitizers (15), fluorescence chemosensors (16) and Langmuir-Blodgett thin films (17).

Besides, aziridino, pyrrolidino, morpholino and tetra(1,4-dioxa-8-azaspiro[4,5]decano) phosphazenes have revealed significant antibacterial, antifungal, and anticancer activities, and they were determined to be efficient in changing the mobility of the DNA (18-21). In such a manner, that some of the cyclophosphazenes were also found to be active in the different tumor cells; e.g. Hep2, HT-29, Hela, C6, Vero, DLD1 and A549 cells (22-24).

In addition, the pyridine derivatives are quite essential compounds with the incredible biological applications $(25,26)$. The new compounds, which contain a trimeric phosphazene ring with 2-pyridyl pendant arm, may be considered to have possibly antimicrobial, anticancer, antituberculosis, and antiproliferative activities.

Consequently, this paper reports herein the salient features of the synthetic and spectroscopic properties of the partly (3) and fully heterocyclic amine substituted spirophosphazene derivatives (3a-3c). 


\section{EXPERIMENTAL PART}

\section{Materials and Methods}

The starting compound, $\mathrm{N}_{3} \mathrm{P}_{3} \mathrm{Cl}_{6}$ (Aldrich) was recrystallized from $\mathrm{n}$-hexane. The solvents and reagents were purified using the standard methods before use. $\mathrm{N}$-methylpropane-1,3diamine, pyridine-2-carboxaldehyde, pyrrolidine, morpholine and 1,4-dioxa-8azaspiro[4,5]decane (DASD) were supplied by Merck. The reactions were performed under Ar and monitored by TLC on Merck DC Alufolien Kiesegel 60 B254 sheets using various solvents. The melting points of the phosphazenes were designated on a Gallenkamp apparatus by capillary tubes. The elemental analyses of the compounds were carried out using a Leco CHNS-932 instrument in microanalytical service of Ankara University. The FTIR spectra were obtained from Jasco FT/IR-430 spectrometer in $\mathrm{KBr}$ disks and reported in $\mathrm{cm}^{-1}$ units. Mass spectra (ESI-MS) of the products were recorded on the Waters 2695 Alliance Micromass ZQ spectrometer. The ${ }^{1} \mathrm{D}\left({ }^{1} \mathrm{H}\right.$ and $\left.{ }^{13} \mathrm{C} N M R\right)$ and ${ }^{2} \mathrm{D}$ (HSQC and HMBC) spectra were monitored on a Varian Mercury FT-NMR (400 MHz) spectrometer using $\mathrm{SiMe}_{4}$ as an internal standard operating at 400.13 and $100.62 \mathrm{MHz}$ (at Ankara University). ${ }^{31} \mathrm{P}$ $\left\{{ }^{1} \mathrm{H}\right\}$ NMR spectra were saved on a Bruker Avance III HD (600 MHz) spectrometer using $85 \% \mathrm{H}_{3} \mathrm{PO}_{4}$ as an external standard operating at $242.94 \mathrm{MHz}$ (at Inönü University). The spectrometer was fitted with a $5 \mathrm{~mm}$ PABBO BB inverse-gradient probe, and standard Bruker pulse programs (27) were used.

Synthesis of 2-pyridyldiamine (2). $\quad N$-(2-Pyridyl)-methyl- $N$ '-methylpropane-1,3diamine (2) was obtained from the reaction of pyridine-2-carboxyaldehyde with $\mathrm{N}$ methylpropane-1,3-diamine in ethanol at $-10{ }^{\circ} \mathrm{C}$ concerning to the published procedure (28).

Synthesis of 2-pyridyl(N/N)spirocyclotriphosphazene (3). A solution of 2 (2.20 g, $12.30 \mathrm{mmol})$ in THF $(100 \mathrm{~mL})$ and triethylamine $(5.70 \mathrm{~mL}, 40.00 \mathrm{mmol})$ was added to a solution of $\mathrm{N}_{3} \mathrm{P}_{3} \mathrm{Cl}_{6}(3.56 \mathrm{~g}, 10.00 \mathrm{mmol})$ in THF $(50 \mathrm{~mL})$ at $-10{ }^{\circ} \mathrm{C}$ under Ar. The mixture was stirred for three days at room temperature, and then it was refluxed for two days. The precipitated triethylamine hydrochloride was filtered off, and the solvent was evaporated at reduced pressure. The product was purified by column chromatography using toluene:THF (2:1) as eluent, and an off-white powder of $\mathbf{3}$ crystallized from toluene. Yield: $2.59 \mathrm{~g}(57 \%)$. mp: $120^{\circ} \mathrm{C}$. Anal. Calcd. for $\mathrm{P}_{3} \mathrm{~N}_{6} \mathrm{Cl}_{4} \mathrm{C}_{10} \mathrm{H}_{15}$ : C, 26.46; H, 3.33; N, 18.51 . Found: C, 25.98; $\mathrm{H}, 3.67 ; \mathrm{N}, 18.41$. ESI-MS (fragments are based on ${ }^{35} \mathrm{Cl}$, Ir \%, Ir designates the fragment abundance percentage): $\mathrm{m} / \mathrm{z} 455\left(\left[\mathrm{M}+\mathrm{H}^{+}, 100\right)\right.$. FTIR $\left(\mathrm{KBr}, \mathrm{cm}^{-}\right.$ ${ }^{1}$ ): $v$ 2924, 2855 (C-H aliph.), 1220 (asymm.), 1169 (symm.) ( $\left.\mathrm{P}=\mathrm{N}\right), 579$ (asymm.), 510 
(symm.) (PCl). ${ }^{1} \mathrm{H} \mathrm{NMR}\left(400 \mathrm{MHz}, \mathrm{CDCl}_{3}, \mathrm{ppm}\right.$, numberings of protons are given in Figure 1): $\delta 8.59\left(\mathrm{~d}, \mathrm{H},{ }^{3} \mathrm{~J}_{\mathrm{HH}}=5.2 \mathrm{~Hz}, H_{5}\right), 7.89\left(\mathrm{dd}, \mathrm{H},{ }^{3} \mathrm{~J}_{\mathrm{HH}}=7.6 \mathrm{~Hz},{ }^{3} \mathrm{~J}_{\mathrm{HH}}=8.0 \mathrm{~Hz}, H_{3}\right), 7.73(\mathrm{~d}, \mathrm{H}$, $\left.{ }^{3} \mathrm{~J}_{\mathrm{HH}}=8.0 \mathrm{~Hz}, \mathrm{H}_{2}\right), 7.38\left(\mathrm{dd}, \mathrm{H},{ }^{3} \mathrm{~J}_{\mathrm{HH}}=5.2 \mathrm{~Hz},{ }^{3} \mathrm{~J}_{\mathrm{HH}}=7.6 \mathrm{~Hz}, H_{4}\right), 4.31\left(\mathrm{~d}, 2 \mathrm{H},{ }^{3} \mathrm{~J}_{\mathrm{PH}}=11.2 \mathrm{~Hz}\right.$, Py- $\left.\mathrm{CH}_{2}-\mathrm{N}\right), 3.20\left(\mathrm{t}, 2 \mathrm{H},{ }^{3} \mathrm{~J}_{\mathrm{PH}}=12.0 \mathrm{~Hz},{ }^{2} \mathrm{~J}_{\mathrm{HH}}=6.0 \mathrm{~Hz}, \mathrm{Py}-\mathrm{CH}_{2}-\mathrm{N}-\mathrm{CH}_{2}\right), 3.15\left(\mathrm{t}, 2 \mathrm{H},{ }^{3} \mathrm{~J}_{\mathrm{PH}}=11.6\right.$ $\left.\mathrm{Hz},{ }^{2} J_{\mathrm{HH}}=5.6 \mathrm{~Hz}, \mathrm{CH}_{3}-\mathrm{N}-\mathrm{CH}_{2}\right), 2.63\left(\mathrm{~d}, 3 \mathrm{H},{ }^{3} \mathrm{~J}_{\mathrm{PH}}=14.0 \mathrm{~Hz}, \mathrm{~N}-\mathrm{CH}_{3}\right), 1.92\left(\mathrm{~m}, 2 \mathrm{H},{ }^{3} \mathrm{~J}_{\mathrm{HH}}=6.0\right.$ $\left.\left.\mathrm{Hz},{ }^{3}\right]_{\mathrm{HH}}=5.2 \mathrm{~Hz}, \mathrm{~N}-\mathrm{CH}_{2}-\mathrm{CH}_{2}\right) \cdot{ }^{13} \mathrm{C} \mathrm{NMR}\left(100 \mathrm{MHz}, \mathrm{CDCl}_{3}, \mathrm{ppm}\right.$, numberings of carbons are given in Figure 1): $\delta 156.79\left(\mathrm{~d},{ }^{3} \mathrm{JPC}_{\mathrm{PC}}=8.5 \mathrm{~Hz}, \mathrm{C}_{1}\right), 147.02\left(\mathrm{~s}, \mathrm{C}_{5}\right), 138.96\left(\mathrm{~s}, \mathrm{C}_{3}\right), 123.18$ $\left(\mathrm{s}, \mathrm{C}_{2}\right), 122.94\left(\mathrm{~s}, \mathrm{C}_{4}\right), 51.44\left(\mathrm{~d},{ }^{2} \mathrm{~J}_{\mathrm{PC}}=3.8 \mathrm{~Hz}, \mathrm{Py}-\mathrm{CH}_{2}-\mathrm{N}\right), 50.03\left(\mathrm{~s}, \mathrm{Py}-\mathrm{CH}_{2}-\mathrm{N}-\mathrm{CH}_{2}\right), 47.16$ (s, $\left.\mathrm{CH}_{3}-\mathrm{N}-\mathrm{CH}_{2}\right), 34.98\left(\mathrm{~d},{ }^{2} \mathrm{~J}_{\mathrm{PC}}=1.5 \mathrm{~Hz}, \mathrm{~N}-\mathrm{CH}_{3}\right), 25.09\left(\mathrm{~d},{ }^{3} \mathrm{JPC}=3.0 \mathrm{~Hz}, \mathrm{~N}-\mathrm{CH}_{2}-\mathrm{CH}_{2}\right)$.

\section{Synthesis of 2-pyridyl(N/N)spirotetrapyrrolidino-cyclotriphosphazene (3a). A} solution of $3(0.80 \mathrm{~g}, 1.80 \mathrm{mmol})$ and triethylamine $(1.00 \mathrm{~mL}, 7.20 \mathrm{mmol})$ in dry THF (100 $\mathrm{mL}$ ) was added slowly to a solution of pyrrolidine $(1.19 \mathrm{~mL}, 14.40 \mathrm{mmol})$ in dry THF (50 $\mathrm{mL}$ ) under Ar. The mixture was stirred for two days at ambient temperature, and then it was refluxed for two days. The crude product was purified by column chromatography using toluene-THF (2:1) as eluent, and an off-white powder of $\mathbf{3 a}$ was crystallized from toluene. Yield: $0.68 \mathrm{~g}(64 \%)$. mp: $169^{\circ} \mathrm{C}$. Anal. Calcd. for $\mathrm{P}_{3} \mathrm{~N}_{10} \mathrm{C}_{26} \mathrm{H}_{47} .0 .5 \mathrm{C}_{7} \mathrm{H}_{8}: \mathrm{C}, 55.50$; $\mathrm{H}, 8.05 ; \mathrm{N}, 21.94$. Found: C 55.66; H, 8.28; N, 21.48. ESI-MS (Ir \%): $m / z 593\left([\mathrm{M}+\mathrm{H}]^{+}\right.$, 100). FTIR ( $\left.\mathrm{KBr}, \mathrm{cm}^{-1}\right): v 2958,2851$ (C-H aliph.), 1225 (asymm.), 1172 (symm.) ( $\left.\mathrm{P}=\mathrm{N}\right)$. ${ }^{1} \mathrm{H}$ NMR $\left(400 \mathrm{MHz}, \mathrm{CDCl}_{3}, \mathrm{ppm}\right): \delta 8.48\left(\mathrm{~d}, \mathrm{H},{ }^{3} \mathrm{~J}_{\mathrm{HH}}=4.2 \mathrm{~Hz}, H_{5}\right), 7.72\left(\mathrm{~d}, \mathrm{H},{ }^{3} \mathrm{~J}_{\mathrm{HH}}=8.0 \mathrm{~Hz}\right.$, $\left.H_{2}\right), 7.63\left(\mathrm{dd}, \mathrm{H},{ }^{3} \mathrm{~J}_{\mathrm{HH}}=7.6 \mathrm{~Hz},{ }^{3} \mathrm{~J}_{\mathrm{HH}}=8.0 \mathrm{~Hz}, \mathrm{H}_{3}\right), 7.12\left(\mathrm{dd}, \mathrm{H},{ }^{3} \mathrm{~J}_{\mathrm{HH}}=6.0 \mathrm{~Hz},{ }^{3} \mathrm{~J}_{\mathrm{HH}}=7.6 \mathrm{~Hz}\right.$, $\left.\mathrm{H}_{4}\right), 4.20\left(\mathrm{~d}, 2 \mathrm{H},{ }^{3} \mathrm{~J}_{\mathrm{PH}}=7.6 \mathrm{~Hz}, \mathrm{Py}-\mathrm{CH}_{2}-\mathrm{N}\right), 3.16\left(\mathrm{~m}, 2 \mathrm{H}, \mathrm{CH}_{3}-\mathrm{N}-\mathrm{CH}_{2}\right), 3.08\left[\mathrm{~m}, 16 \mathrm{H}, \mathrm{N}-\mathrm{CH}_{2}\right.$ (pyrr) ], $3.07\left(\mathrm{~m}, 2 \mathrm{H}, \mathrm{Py}-\mathrm{CH}_{2}-\mathrm{N}-\mathrm{CH}_{2}\right), 2.60\left(\mathrm{~d}, 3 \mathrm{H},{ }^{3} \mathrm{~J}_{\mathrm{PH}}=13.6 \mathrm{~Hz}, \mathrm{~N}-\mathrm{CH}_{3}\right), 1.79(\mathrm{~m}, 2 \mathrm{H}$, ${ }^{3} J_{\mathrm{HH}}=5.2 \mathrm{~Hz}, \mathrm{~N}-\mathrm{CH}_{2}-\mathrm{CH}_{2}$ ), $1.78\left[\mathrm{~m}, 8 \mathrm{H}, \mathrm{N}-\mathrm{CH}_{2}-\mathrm{CH}_{2}\right.$ (pyrr)], $1.64\left[\mathrm{~m}, 8 \mathrm{H}, \mathrm{N}-\mathrm{CH}_{2}-\mathrm{CH}_{2}\right.$ (pyrr)]. ${ }^{13} \mathrm{C}$ NMR $\left(100 \mathrm{MHz}, \mathrm{CDCl}_{3}, \mathrm{ppm}\right): \delta 161.16\left(\mathrm{~d},{ }^{3} \mathrm{JC}_{\mathrm{PC}}=11.6 \mathrm{~Hz}, \mathrm{C}_{1}\right), 148.68\left(\mathrm{~s}, \mathrm{C}_{5}\right), 136.45$ $\left(\mathrm{s}, C_{3}\right), 121.72\left(\mathrm{~s}, \mathrm{C}_{2}\right), 121.61\left(\mathrm{~s}, \mathrm{C}_{4}\right), 52.78\left(\mathrm{~d},{ }^{2} \mathrm{~J}_{\mathrm{PC}}=2.9 \mathrm{~Hz}, \mathrm{Py}-\mathrm{CH}_{2}-\mathrm{N}\right), 50.99\left(\mathrm{~s}, \mathrm{Py}-\mathrm{CH}_{2}-\right.$ $\left.\mathrm{N}-\mathrm{CH}_{2}\right), 47.09\left(\mathrm{~s}, \mathrm{CH}_{3}-\mathrm{N}-\mathrm{CH}_{2}\right), 46.20$ and $46.18\left[\mathrm{~s}, \mathrm{~N}-\mathrm{CH}_{2}\right.$ (pyrr)], $36.36\left(\mathrm{~m}, \mathrm{~N}-\mathrm{CH}_{3}\right), 26.29$ $\left[\left(d,{ }^{3}\right]_{\mathrm{PC}}=6.9 \mathrm{~Hz}, \mathrm{~N}-\mathrm{CH}_{2}-\mathrm{CH}_{2}\right.$ (pyrr) $], 26.22\left[\left(\mathrm{~d},{ }^{3}\right]_{\mathrm{PC}}=6.1 \mathrm{~Hz}, \mathrm{~N}-\mathrm{CH}_{2}-\mathrm{CH}_{2}\right.$ (pyrr) $], 25.01$ (d, ${ }^{3} J_{\mathrm{PC}}=2.9 \mathrm{~Hz}, \mathrm{~N}-\mathrm{CH}_{2}-\mathrm{CH}_{2}$ ).

Synthesis of 2-pyridyl(N/N)spirotetramorpholino-cyclotriphosphazene (3b). The experimental procedure was carried out as in $\mathbf{3 a}$, using $\mathbf{3}(0.80 \mathrm{~g}, 1.80 \mathrm{mmol})$, triethylamine $(1.00 \mathrm{~mL}, 7.20 \mathrm{mmol})$ and morpholine $(1.25 \mathrm{~mL}, 14.40 \mathrm{mmol})$. The mixture was stirred for two days at ambient temperature, and then it was refluxed for three days. The crude product was purified by column chromatography using toluene-THF $(2: 1)$ as eluent, and an off-white powder of $\mathbf{3 b}$ crystallized from toluene. Yield: $0.66 \mathrm{~g}(56 \%)$. mp: $145{ }^{\circ} \mathrm{C}$. Anal. Calcd. for $\mathrm{P}_{3} \mathrm{~N}_{10} \mathrm{O}_{4} \mathrm{C}_{26} \mathrm{H}_{47} .0 .5 \mathrm{C}_{7} \mathrm{H}_{8}$ : C, 50.45; $\mathrm{H}, 7.32 ; \mathrm{N}, 19.94$. Found: $\mathrm{C}$, 50.93; H, 7.38; N, 20.05. ESI-MS (Ir \%): $\mathrm{m} / z 657\left([\mathrm{M}+\mathrm{H}]^{+}, 100\right)$. FTIR $\left(\mathrm{KBr}, \mathrm{cm}^{-1}\right): v$ 
2918, 2851 (C-H aliph.), 1248 (asymm.), 1159 (symm.) ( $\mathrm{P}=\mathrm{N}) .{ }^{1} \mathrm{H}$ NMR (400 MHz, CDCl ppm): $\delta 8.55\left(\mathrm{~d}, \mathrm{H},{ }^{3} \mathrm{~J}_{\mathrm{HH}}=4.8 \mathrm{~Hz}, \mathrm{H}_{5}\right), 7.45\left(\mathrm{~d}, \mathrm{H},{ }^{3} \mathrm{~J}_{\mathrm{HH}}=8.0 \mathrm{~Hz}, \mathrm{H}_{2}\right), 7.30\left(\mathrm{dd}, \mathrm{H}^{3}{ }^{3} \mathrm{JHH}_{\mathrm{H}}=8.0\right.$ $\left.\mathrm{Hz},{ }^{3} \mathrm{~J}_{\mathrm{HH}}=8.0 \mathrm{~Hz}, H_{3}\right), 7.18\left(\mathrm{dd}, \mathrm{H},{ }^{3} \mathrm{~J}_{\mathrm{HH}}=4.4 \mathrm{~Hz},{ }^{3} \mathrm{~J}_{\mathrm{HH}}=8.0 \mathrm{~Hz}, H_{4}\right), 4.32\left(\mathrm{~d}, 2 \mathrm{H},{ }^{3} \mathrm{~J}_{\mathrm{PH}}=9.6 \mathrm{~Hz}\right.$, Py- $\mathrm{CH}_{2}-\mathrm{N}$ ), $3.69\left[\mathrm{~m}, 8 \mathrm{H}, \mathrm{O}-\mathrm{CH}_{2}\right.$ (morp)], $3.65\left[\mathrm{~m}, 8 \mathrm{H}, \mathrm{O}-\mathrm{CH}_{2}\right.$ (morp)], 3.21 (t, 2H, $\left.{ }^{3} \mathrm{~J}_{\mathrm{PH}}=12.0 \mathrm{~Hz},{ }^{2} \mathrm{~J}_{\mathrm{HH}}=6.0 \mathrm{~Hz}, \mathrm{Py}-\mathrm{CH}_{2}-\mathrm{N}-\mathrm{CH}_{2}\right), 3.16\left[\mathrm{~m}, 16 \mathrm{H}, \mathrm{N}-\mathrm{CH}_{2}\right.$ (morp)], $3.12(\mathrm{t}, 2 \mathrm{H}$, $\left.{ }^{3} \mathrm{~J}_{\mathrm{PH}}=11.2 \mathrm{~Hz},{ }^{2} \mathrm{~J}_{\mathrm{HH}}=5.6 \mathrm{~Hz}, \mathrm{CH}_{3}-\mathrm{N}-\mathrm{CH}_{2}\right), 2.69\left(\mathrm{~d}, 3 \mathrm{H},{ }^{3} \mathrm{~J}_{\mathrm{PH}}=11.6 \mathrm{~Hz}, \mathrm{~N}-\mathrm{CH}_{3}\right), 1.97(\mathrm{~m}, 2 \mathrm{H}$, $\left.{ }^{3} \mathrm{~J}_{\mathrm{HH}}=7.2 \mathrm{~Hz},{ }^{3} \mathrm{~J}_{\mathrm{HH}}=7.2 \mathrm{~Hz}, \mathrm{~N}-\mathrm{CH}_{2}-\mathrm{CH}_{2}\right) .{ }^{13} \mathrm{C} \mathrm{NMR}\left(100 \mathrm{MHz}, \mathrm{CDCl}_{3}, \mathrm{ppm}\right): \delta 157.45$ (d, $\left.{ }^{3} \mathrm{JPC}_{\mathrm{PC}}=6.1 \mathrm{~Hz}, \mathrm{C}_{1}\right), 149.45\left(\mathrm{~s}, \mathrm{C}_{5}\right), 137.17\left(\mathrm{~s}, \mathrm{C}_{3}\right), 122.77\left(\mathrm{~s}, \mathrm{C}_{2}\right), 121.66\left(\mathrm{~s}, \mathrm{C}_{4}\right), 67.10$ [(d, ${ }^{3} \mathrm{~J}_{\mathrm{PC}}=7.7 \mathrm{~Hz}, \mathrm{O}-\mathrm{CH}_{2}$ (morp)], 66.87 [(s, O- $\mathrm{CH}_{2}$ (morp)], 52.18 (d, $\left.{ }^{2} \mathrm{JPC}_{\mathrm{PC}}=2.8 \mathrm{~Hz}, \mathrm{Py}-\mathrm{CH}_{2}-\mathrm{N}\right)$, 50.49 (s, Py- $\left.\mathrm{CH}_{2}-\mathrm{N}-\mathrm{CH}_{2}\right), 46.99\left(\mathrm{~s}, \mathrm{CH}_{3}-\mathrm{N}-\mathrm{CH}_{2}\right), 44.96$ and 44.70 [s, N-CH (morp)], 35.61 $\left(\mathrm{d},{ }^{2} \mathrm{~J}_{\mathrm{PC}}=3.1 \mathrm{~Hz}, \mathrm{~N}-\mathrm{CH}_{3}\right), 25.07\left(\mathrm{~d},{ }^{3} \mathrm{~J}_{\mathrm{PC}}=3.1 \mathrm{~Hz}, \mathrm{~N}-\mathrm{CH}_{2}-\mathrm{CH}_{2}\right)$.

Synthesis of 2-pyridyI(N/N)spirotetra-DASD-cyclotriphosphazene (3c). The experimental procedure was carried out as in $\mathbf{3 a}$, using $\mathbf{3}(0.80 \mathrm{~g}, 1.80 \mathrm{mmol})$, triethylamine $(1.00 \mathrm{~mL}, 7.20 \mathrm{mmol})$ and DASD $(1.85 \mathrm{~mL}, 14.40 \mathrm{mmol})$. The mixture was stirred for two days at ambient temperature, and then it was refluxed for two days. The crude product was purified by column chromatography using toluene-THF (2:1) as eluent, and an off-white powder of $3 \mathrm{c}$ crystallized from toluene. Yield: $0.95 \mathrm{~g}(60 \%)$. mp: $177^{\circ} \mathrm{C}$. Anal. Calcd. for $\mathrm{P}_{3} \mathrm{~N}_{10} \mathrm{O}_{8} \mathrm{C}_{38} \mathrm{H}_{63}$ : C, 51.84; $\mathrm{H}, 7.21 ; \mathrm{N}, 15.91$. Found: $\mathrm{C}, 51.49 ; \mathrm{H}, 7.33 ; \mathrm{N}$, 15.46. ESI-MS (Ir \%): $m / z 881\left([\mathrm{M}+\mathrm{H}]^{+}, 100\right)$. FTIR $\left(\mathrm{KBr}, \mathrm{cm}^{-1}\right): v 2918,2851(\mathrm{C}-\mathrm{H}$ aliph.), 1216 (asymm.), 1152 (symm.) ( $\mathrm{P}=\mathrm{N}) .{ }^{1} \mathrm{H} \mathrm{NMR}\left(400 \mathrm{MHz}, \mathrm{CDCl}_{3}, \mathrm{ppm}\right): \delta 8.49$ (d, $\left.\mathrm{H},{ }^{3} \mathrm{~J}_{\mathrm{HH}}=4.8 \mathrm{~Hz}, H_{5}\right), 7.68\left(\mathrm{dd}, \mathrm{H},{ }^{3} \mathrm{~J}_{\mathrm{HH}}=6.0 \mathrm{~Hz},{ }^{3} \mathrm{~J}_{\mathrm{HH}}=7.6 \mathrm{~Hz}, H_{3}\right), 7.65\left(\mathrm{~d}, \mathrm{H},{ }^{3} \mathrm{~J}_{\mathrm{HH}}=7.6 \mathrm{~Hz}\right.$, $\left.\mathrm{H}_{2}\right), 7.13\left(\mathrm{dd}, \mathrm{H},{ }^{3} \mathrm{~J}_{\mathrm{HH}}=6.0 \mathrm{~Hz},{ }^{3} \mathrm{~J}_{\mathrm{HH}}=7.6 \mathrm{~Hz}, \mathrm{H}_{4}\right), 4.11\left(\mathrm{~d}, 2 \mathrm{H},{ }^{3} \mathrm{JPH}_{\mathrm{PH}}=7.6 \mathrm{~Hz}, \mathrm{Py}-\mathrm{CH}_{2}-\mathrm{N}\right), 3.95$ [s, 8H, O-CH2 (DASD)], 3.89 [s, 8H, O-CH2 (DASD)], $3.22\left[\mathrm{~m}, 16 \mathrm{H}, \mathrm{N}-\mathrm{CH}_{2}\right.$ (DASD)], 3.14 $\left(\mathrm{m}, 2 \mathrm{H}, \mathrm{Py}-\mathrm{CH}_{2}-\mathrm{N}-\mathrm{CH}_{2}\right), 3.05\left(\mathrm{~m}, 2 \mathrm{H}, \mathrm{CH}_{3}-\mathrm{N}-\mathrm{CH}_{2}\right), 2.54\left(\mathrm{~d}, 3 \mathrm{H},{ }^{3} \mathrm{JPH}_{\mathrm{PH}}=13.6 \mathrm{~Hz}, \mathrm{~N}-\mathrm{CH}_{3}\right), 1.81$ $\left(\mathrm{m}, 2 \mathrm{H}, \mathrm{N}-\mathrm{CH}_{2}-\mathrm{CH}_{2}\right), 1.65\left[\mathrm{~m}, 8 \mathrm{H}, \mathrm{N}-\mathrm{CH}_{2}-\mathrm{CH}_{2}\right.$ (DASD)], $1.52\left[\mathrm{~m}, 8 \mathrm{H}, \mathrm{N}-\mathrm{CH}_{2}-\mathrm{CH}_{2}\right.$ (DASD)]. ${ }^{13} \mathrm{C} \mathrm{NMR}\left(100 \mathrm{MHz}, \mathrm{CDCl}_{3}, \mathrm{ppm}\right): \delta 160.16\left(\mathrm{~d},{ }^{3} \mathrm{~J}_{\mathrm{PC}}=7.5 \mathrm{~Hz}, \mathrm{C}_{1}\right), 148.64$ (s, $\left.\mathrm{C}_{5}\right), 136.57$ (s, $\left.C_{3}\right), 125.45\left(\mathrm{~s}, C_{2}\right), 121.74\left(\mathrm{~s}, C_{4}\right), 107.79$ and 107.52 [s, O-C-O (DASD)], 64.16 and $64.07\left[\mathrm{~s}, \mathrm{O}-\mathrm{CH}_{2}\right.$ (DASD)], $52.63\left(\mathrm{~d},{ }^{2} \mathrm{~J}_{\mathrm{PC}}=3.0 \mathrm{~Hz}, \mathrm{Py}-\mathrm{CH}_{2}-\mathrm{N}\right), 50.83\left(\mathrm{~s}, \mathrm{Py}-\mathrm{CH}_{2}-\mathrm{N}-\mathrm{CH}_{2}\right)$, $47.16\left(\mathrm{~s}, \mathrm{CH}_{3}-\mathrm{N}-\mathrm{CH}_{2}\right), 42.77$ and $42.68\left[\mathrm{~s}, \mathrm{~N}-\mathrm{CH}_{2}\right.$ (DASD)], $36.31\left(\mathrm{~m}, \mathrm{~N}-\mathrm{CH}_{3}\right), 35.65$ and $35.44\left[\mathrm{~m}, \mathrm{~N}-\mathrm{CH}_{2}-\mathrm{CH}_{2}\right.$ (DASD)], $25.16\left(\mathrm{~d},{ }^{3} \mathrm{JPC}_{\mathrm{PC}}=3.0 \mathrm{~Hz}, \mathrm{~N}-\mathrm{CH}_{2}-\mathrm{CH}_{2}\right)$. 
<smiles>ClP1(Cl)=NP(Cl)(Cl)=NP(Cl)(Cl)=N1</smiles>

(1)
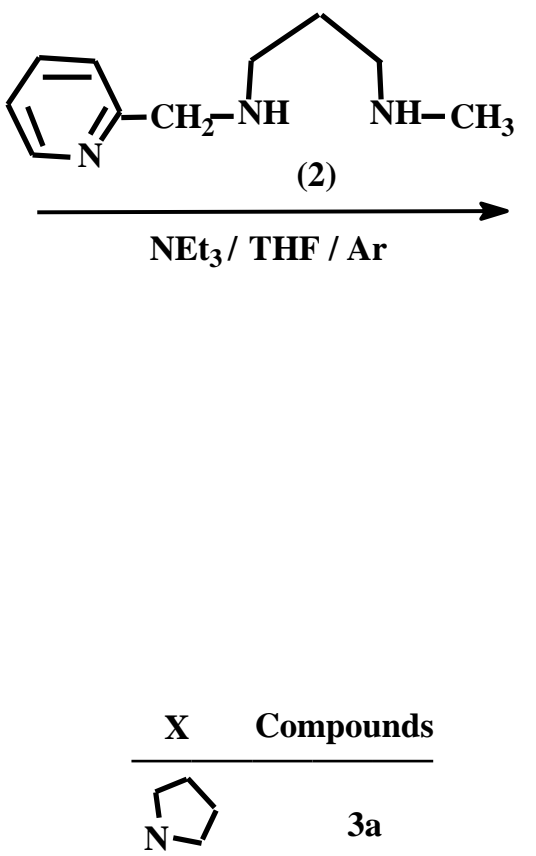

><smiles>CN1CCCN(Cc2ccccn2)P12=NP(Cl)(Cl)=NP(Cl)(Cl)=N2</smiles>

spiro tetrachlorophosphazene (3) \begin{tabular}{c|} 
Secondary amines \\
NEt $_{3}$
\end{tabular}$\downarrow$ THF / Ar<smiles>[Y][X]1([Y])=NP([X])([X])=NP2(=N1)N(C)CCCN2Cc1ccccn1</smiles>

spiro tetraaminophosphazenes

Figure 1. The synthesis of 2-pyridylspiro(N/N)cyclotriphosphazene (3) and its tetraamino derivatives $(\mathbf{3 a - 3} \mathbf{c})$.

\section{RESULTS AND DISCUSSION}

\section{Syntheses}

The reaction of pyridine-2-carboxyaldehyde with $N$-methylpropane-1,3-diamine led to the formation of the intermediate Schiff base. This product was reduced with $\mathrm{NaBH}_{4}$ in ethanol to produce the difunctional ligand, $N$-(2-pyridyl)-methyl- $N$ '-methylpropane-1,3-diamine (2), in accordance with the literature (28). The preliminary spiro cyclotriphosphazene; 2pyridyl(N/N)spiro cyclotriphosphazene (3), was prepared from the reaction of $\mathrm{N}_{3} \mathrm{P}_{3} \mathrm{Cl}_{6}$ with one equimolar amount of the 2-pyridyldiamine (2) with a yield of $57 \%$ in dry THF. The condensation reactions of $\mathbf{3}$ with excess pyrrolidine, morpholine and 1,4-dioxa-8azaspiro[4,5]decane (DASD) afforded the fully amino substituted cyclotriphosphazenes $(3 a-3 c)$. The estimating yields of these products were found to be 64,56 and $60 \%$, respectively (Figure 1 ). 
The structures of the 2-pyridylspiro(N/N)cyclotriphosphazenes with a half mole of toluene for $\mathbf{3} \mathbf{a}$ and $\mathbf{3 b}$, were characterized by the elemental analyses, ESI-MS, FTIR, HSQC, HMBC, ${ }^{1} \mathrm{H},{ }^{13} \mathrm{C}$ and ${ }^{31} \mathrm{P}$ NMR techniques. The analytical and $\mathrm{NMR}$ results are given in the "Experimental Part". The ESI-MS spectra of all the trimeric phosphazenes exhibit the protonated molecular $[\mathrm{MH}]^{+}$ion peaks. The first leaving group in the ESI-MS spectra of the fully substituted compounds (3a-3c) was determined as 2-pyridyl-methyl $\left[\mathrm{M}-\mathrm{C}_{5} \mathrm{H}_{4} \mathrm{~N}-\mathrm{CH}_{2}\right.$, 92].

\section{NMR and IR Spectroscopy}

The ${ }^{31} \mathrm{P} \quad\left\{{ }^{1} \mathrm{H}\right\} \quad$ NMR chemical shifts and the coupling constants of 2pyridylspiro(N/N)cyclotriphosphazenes (3 and $\mathbf{3 a - 3 c}$ ) are tabulated in Table 1. The ${ }^{31} \mathrm{P}$ spectra of all the compounds display $\mathrm{AX}_{2}$ type spectra on account of two different phosphorus environments within the structures, and they appear as one doublet $(\mathrm{Px})$ and one triplet $\left(\mathrm{P}_{\text {spiro, }} \mathrm{P}_{\mathrm{A}}\right)$. It is determined that the $\delta \mathrm{P}_{\text {spiro }}$ chemical shifts of all the tetraamino2-pyridylspiro(N/N)cyclotriphosphazenes (3a-3c) are higher than the compound $\mathbf{3}$. As known, in compound 3, the $\mathrm{Cl}$ atoms are withdrawing the electrons of the phosphazene ring. Hence, electrons are releasing from the nitrogen atoms of the spiro ring to the phosphazene skeleton and negative hyperconjugation occurs on the spiro phosphorus atom (29). This is reversed for the amino phosphazenes (3a-3c). On the contrary, the coupling constants of all the phosphazenes are nearly the same.

As examples, ${ }^{31} \mathrm{P}\left\{{ }^{1} \mathrm{H}\right\}$ NMR spectra of the beginning spiro compound (3) and its morpholine substituted derivative ( $\mathbf{3 b}$ ) are depicted in Figure 2 . In the spectra of $\mathbf{3}$ and $\mathbf{3 b}$, the $\delta \mathrm{P}_{\mathrm{A}}$ of spiro ( $\left.\mathrm{P}_{\mathrm{NN}}\right)$ and $\delta \mathrm{Px}_{\mathrm{x}}\left(\mathrm{P}_{\mathrm{Cl}}\right.$ or $\left.\mathrm{P}_{\mathrm{NN}}\right)$ are 11.66 and $23.25 \mathrm{ppm}$, and 22.02 and $20.14 \mathrm{ppm}$, respectively. The ${ }^{2} J_{\mathrm{PP}}$ values of both are calculated as $38.9 \mathrm{~Hz}$.

X: CI, Pyrrolidine, Morpholine, DASD

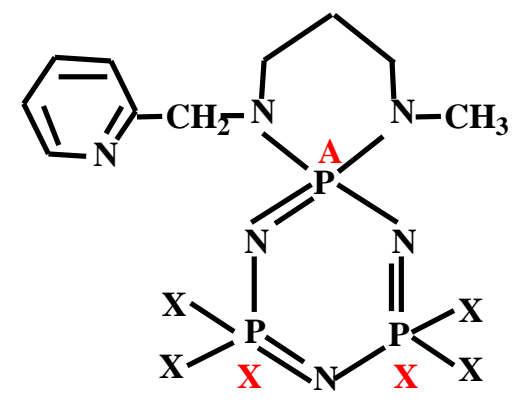

$\mathrm{AX}_{2}(3,3 \mathrm{a}, 3 \mathrm{~b}$ and $3 \mathrm{c})$ 


\begin{tabular}{|c|c|c|c|c|c|}
\hline $\begin{array}{l}\text { Compoun } \\
\text { d }\end{array}$ & $\begin{array}{l}\text { Spin } \\
\text { Systems }\end{array}$ & $\begin{array}{l}\mathbf{P A}_{\mathrm{A}} \\
\left(\mathbf{P}_{\mathrm{NN}}\right)\end{array}$ & $\begin{array}{l}P_{x} \\
\left(P_{N N}\right)\end{array}$ & $\begin{array}{l}\mathbf{P x} \\
\left(\mathbf{P c I}_{\mathrm{C}}\right)\end{array}$ & ${ }^{2} J_{\mathrm{PP}}(\mathrm{Hz})$ \\
\hline 3 & $A X_{2}$ & $11.66(t)$ & - & $22.02(d)$ & $\mathbf{2}_{\mathrm{AX}} 38.9$ \\
\hline $3 \mathbf{a}$ & $A X_{2}$ & $23.79(t)$ & $17.39(\mathrm{~d})$ & - & $\mathbf{2}_{\mathbf{A X}} 38.9$ \\
\hline $\begin{array}{l}3 \mathbf{b} \\
\mathbf{3 c}\end{array}$ & $\begin{array}{l}A X_{2} \\
A X_{2}\end{array}$ & $\begin{array}{l}23.25(t) \\
23.00(t)\end{array}$ & $\begin{array}{l}20.14(d) \\
20.33(d)\end{array}$ & - & $\begin{array}{l}{ }^{2} J_{\text {AX }} 38.9 \\
2 J_{\text {AX }} 36.4\end{array}$ \\
\hline
\end{tabular}

Table 1. ${ }^{31} \mathrm{P}\left\{{ }^{1} \mathrm{H}\right\}$ NMR data of 2-pyridyl(N/N)spirocyclotriphosphazenes. ${ }^{a}$

${ }^{a} 242.925 \mathrm{MHz}{ }^{31} \mathrm{P}$ NMR measurements in $\mathrm{CDCl}_{3}$ solutions at $298 \mathrm{~K}$, and the chemical shifts referenced to external standard $\mathrm{H}_{3} \mathrm{PO}_{4}$.

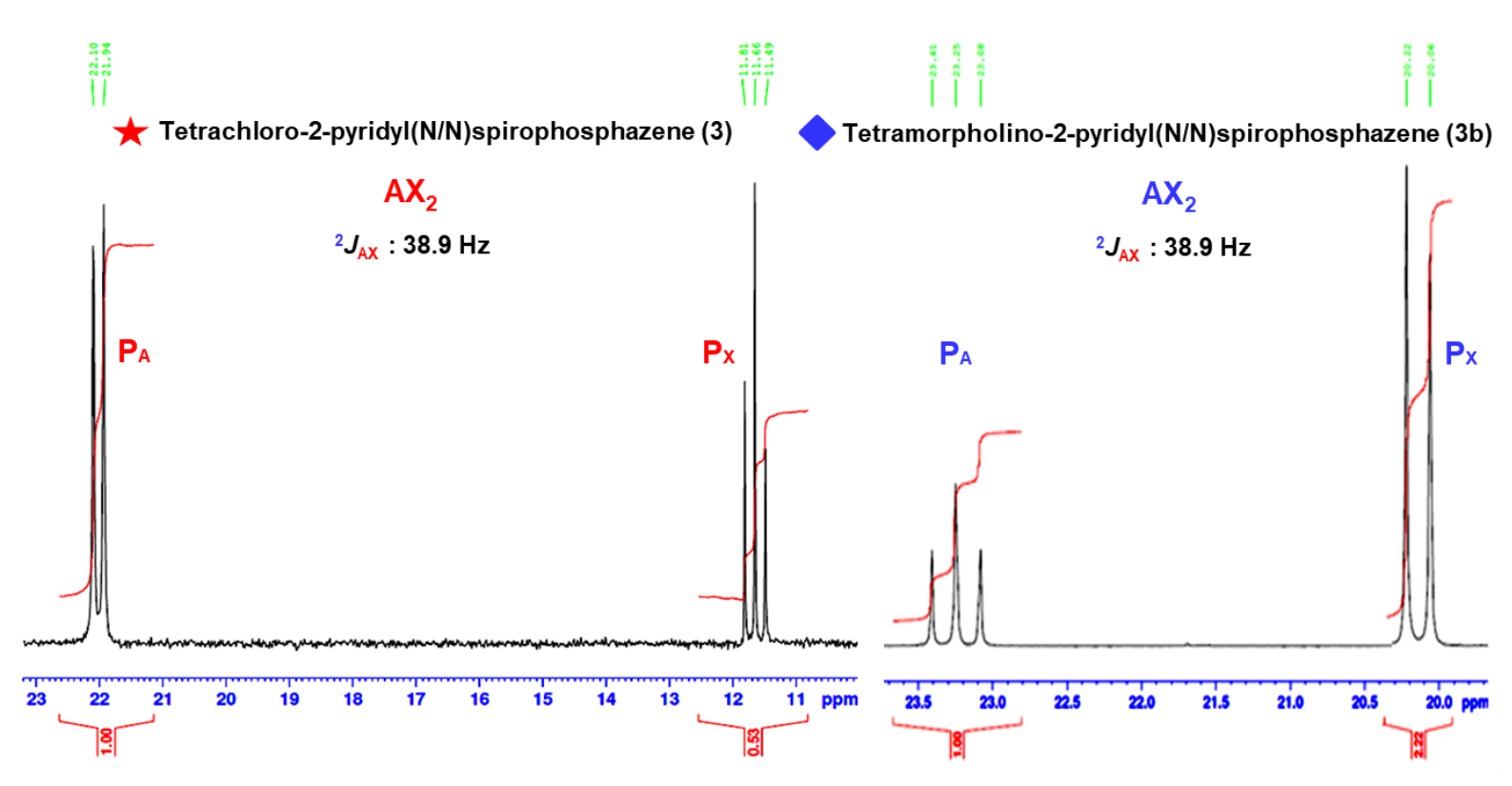

Figure 2. ${ }^{31} \mathrm{P}\left\{{ }^{1} \mathrm{H}\right\}$ NMR spectra of the compounds $\mathbf{3}$ and $\mathbf{3 b}$.

The interpretations of the $\delta$ chemical shifts, multiplicities, and $J$ coupling constants are elucidated from the ${ }^{13} \mathrm{C}$ and ${ }^{1} \mathrm{H} \quad \mathrm{NMR}$ spectra of the new 2pyridyl(N/N)spirocyclotriphosphazenes (3 and 3a-3c), and presented in "Experimental Part". The HSQC [using values corresponding to ${ }^{1} \mathrm{~J}_{\mathrm{CH}}$ ] and $\mathrm{HMBC}$ [using values corresponding to ${ }^{2} \mathrm{~J}_{\mathrm{CH}},{ }^{3} \mathrm{~J}_{\mathrm{CH}}$ and ${ }^{4} \mathrm{~J}_{\mathrm{CH}}$ between the protons and carbons] are also quite useful for the assignments of the signals. The HMBC and HSQC spectra of $\mathbf{3 a}$ are given in Figures $3 a$ and $3 b$, respectively, as examples. 
a)

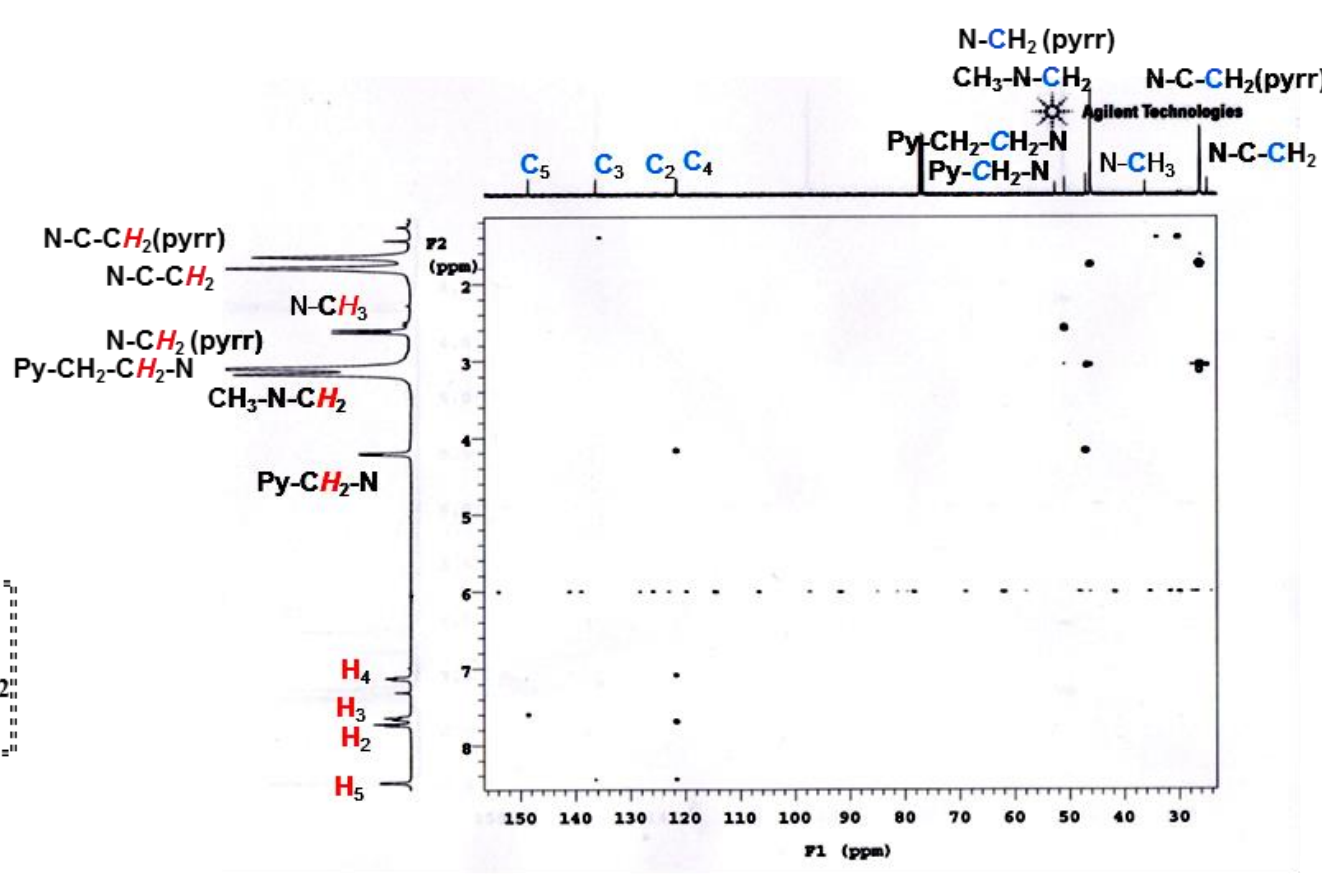

b)

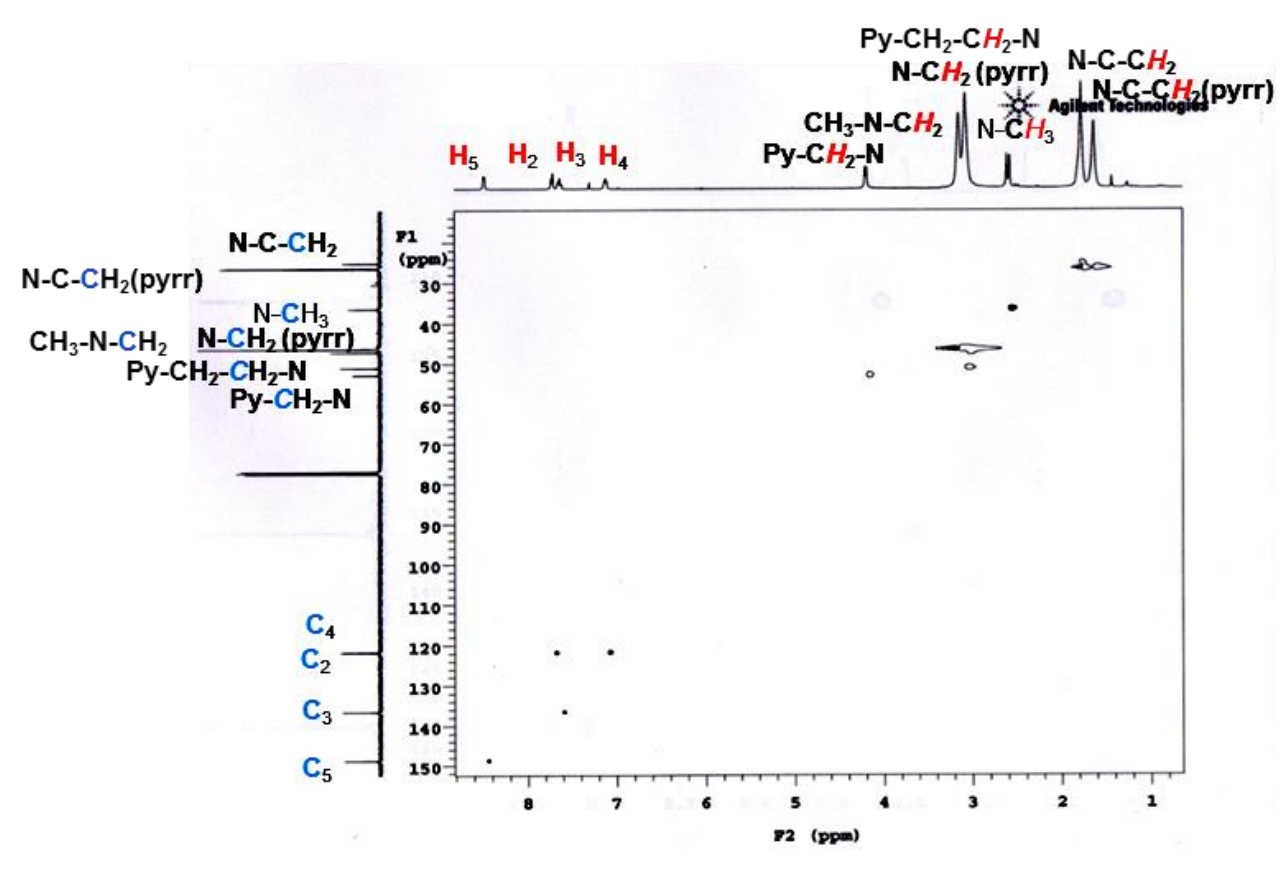

Figure 3. The (a) HMBC and (b) HSQC spectra of $\mathbf{3 a}$.

The signals of all the carbons of the 2-pyridyl(N/N)spirocyclotriphosphazenes are interpreted in the ${ }^{13} \mathrm{C}$ NMR spectra. The $\mathrm{N}-\underline{C} \mathrm{H}_{3}$ carbons of the phosphazenes are observed in the range of $34.98-36.36 \mathrm{ppm}$, and the average value is $35.88 \mathrm{ppm}$. The average values of ${ }^{3} J_{\text {PNCC }}$, for the $\mathrm{N}-\mathrm{CH}_{2}-\underline{C} \mathrm{H}_{2}$ carbons of the cyclotriphosphazene derivatives are $6.5 \mathrm{~Hz}$ (for pyrrolidine rings), $7.7 \mathrm{~Hz}$ (for morpholine) and $3.0 \mathrm{~Hz}$ (for six-membered NN spiro rings). In contrast with, the ${ }^{2} J_{\underline{P} N \underline{C}}$, for the $\mathrm{Py}-\mathrm{CH}_{2}-\mathrm{N}-\underline{\mathrm{C}} \mathrm{H}_{2}$ and $\mathrm{CH}_{3}-\mathrm{N}-\underline{\mathrm{C}} \mathrm{H}_{2}$ carbons of the compounds are not observed. As expected, the geminal amine substituents in the ${ }^{13} \mathrm{C}$ spectra of the tetraaminocyclotriphosphazenes (3a-3c) displayed two small separated peaks for $\mathrm{N}-\underline{\mathrm{C}} \mathrm{H}_{2}$, 


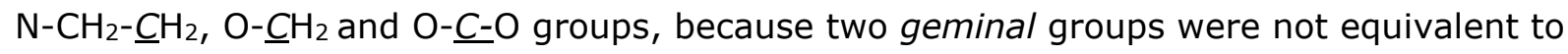
each other. The $\mathrm{O}-\underline{\mathrm{C}}-\mathrm{O}$ and $\mathrm{C}-\mathrm{O}-\underline{\mathrm{C}} \mathrm{H}_{2}$ carbon signals of $\mathbf{3 c}$ are very characteristic, and they are observed at $\mathrm{ca} .107$ and $64 \mathrm{ppm}$ as four separate singlets. The $\mathrm{O}-\underline{\mathrm{C}} \mathrm{H}_{2}$ carbons of tetramorpholino-2-pyridyl(N/N)spirocyclotriphosphazene (3b) also appear at ca. $67 \mathrm{ppm}$ as two separate singlets. On the other hand, the expected carbon peaks $\left(C_{1}-C_{5}\right)$ of the pyridyl ring are assigned from the ${ }^{13} \mathrm{C}$ NMR spectra of all the compounds, and the obtained results are consistent with the literature findings of 2-pyridyl substituted derivatives (28).

The ${ }^{3} J_{\text {PNCC }}$ values of the tetrapyrrolidino-2-pyridyl(N/N)spirocyclotriphosphazenes (3a) reveal to triplets of the $\mathrm{N}-\mathrm{CH}_{2}-\underline{C H}_{2}$ carbons on account of the second-order effects that have also been observed previously for some of the cyclotriphosphazenes $(30,31)$ (Figure 4). The ${ }^{3} J_{\text {PNCC }}$ values were estimated using the external transitions of the triplet peaks.

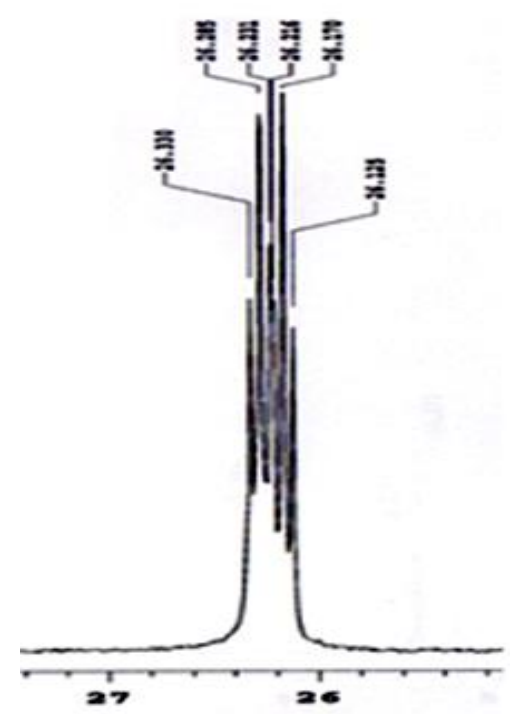

Figure 4. The second order effect in ${ }^{13} \mathrm{C}\left\{{ }^{1} \mathrm{H}\right\}$ NMR spectrum of $\mathbf{3 a}$.

The signals of the protons of the 2-pyridyl $(\mathrm{N} / \mathrm{N})$ spirocyclotriphosphazenes are evaluated in the ${ }^{1} \mathrm{H}$ NMR spectra. The ${ }^{1} \mathrm{H}$ NMR spectra of the fully substituted phosphazenes (3a-3c) show that four secondary monoamines (pyrrolidine, morpholine and DASD) were bonded to the $\mathrm{P} 2$ and $\mathrm{P} 3$ atoms (see numbering of trimer in Figure 1). The average values of $\mathrm{N}$ $\mathrm{CH}_{2}-\underline{C}_{2}, \mathrm{Py}-\mathrm{CH}_{2}-\mathrm{N}-\underline{C}_{2}$ and $\mathrm{CH}_{3}-\mathrm{N}-\underline{C}_{2}$ spiro protons of the phosphazenes (3a-3c) were found to be at $1.86 \mathrm{ppm}, 3.14 \mathrm{ppm}$ and $3.12 \mathrm{ppm}$, respectively, in comparison to the values (1.92 ppm, $3.20 \mathrm{ppm}$ and $3.15 \mathrm{ppm}$ ) of the starting phosphazene (3). Furthermore, the $\delta_{\mathrm{H}}$ shift of the protons of $\mathrm{Py}-\mathrm{C}_{2}-\mathrm{N}$ of the compounds was observed in the range of 4.11-4.32 ppm, and the average ${ }^{3} \mathrm{JPH}_{\mathrm{PH}}$ value is $9.0 \mathrm{~Hz}$. On the other hand, the expected proton peaks $\left(\mathrm{H}_{2}-\mathrm{H}_{5}\right)$ of the pyridyl ring were determined from the ${ }^{1} \mathrm{H}$ NMR spectra of all the compounds, and the finding data are in accordance with the literature (28). The $\mathrm{N}-\mathrm{CH}_{3}$ 
protons of the cyclotriphosphazenes were observed in the range of 2.54-2.69 ppm, and the average ${ }^{3} \mathrm{PH}_{\mathrm{PH}}$ value, $13.2 \mathrm{~Hz}$, was very large.

The characteristic FTIR bands of the 2-pyridyl(N/N)spirocyclotriphosphazenes are given in "Experimental Part". The compounds exhibited intense asymmetric and symmetric stretching vibrations between $1216-1248 \mathrm{~cm}^{-1}$ and $1152-1172 \mathrm{~cm}^{-1}$, ascribed to the $\mathrm{P}=\mathrm{N}$ bonds of the $\mathrm{P}_{3} \mathrm{~N}_{3}$ skeletons (32). As expected, the asymmetric and symmetric vibrations of $V \mathrm{PCl} 2$ for the partly substituted phosphazene (3) emerged at $579 \mathrm{~cm}^{-1}$ and $510 \mathrm{~cm}^{-1}$, respectively (33). In other compounds (3a-3c), these peaks disappeared.

\section{CONCLUSIONS}

The reactions of $\mathrm{N}_{3} \mathrm{P}_{3} \mathrm{Cl}_{6}$ (1) with one equimolar amount of the 2-pyridyl substituted $\mathrm{N} / \mathrm{N}$ donor-type bidentate ligand (2) produced 2-pyridyl(N/N)spirocyclotriphosphazene (3) regioselectively in dry THF. The partly substituted spiro compound (3) reacted with excess secondary amines in THF to afford the fully substituted cyclotriphosphazenes (3a-3c). The obtained 2-pyridyl(N/N)spirocyclotriphosphazenes (3 and 3a-3c) are the first examples of the pyridyl pendant armed cyclotriphosphazenes. The spectroscopic features of the cyclophosphazenes were scrutinized using one and two dimensional NMR techniques in $\mathrm{CDCl}_{3}$ solution. The synthetic and spectroscopic properties of the compounds were compared to each other. As known, the aminospirocyclotriphosphazenes are strong bases. Thus, the tetraamino-2-pyridyl(N/N)spirocyclotriphosphazenes synthesized in this paper ought to be used as heterocyclic ligands for the transition metal cations, and they may be produced phosphazenium salts with biologically active bulky organic acids. Moreover, 2pyridyl-diamine (2), which is a pyridine derivative, is very essential chemical with great biological applications. Hence, the obtained new phosphazene derivatives ( $\mathbf{3}$ and $\mathbf{3 a - 3 \mathbf { c }}$ ), which contain a trimeric phosphazene ring with 2-pyridyl pendant arm, are considered to have probably anticancer, antituberculosis, antimicrobial, antiviral and antiproliferative activities.

\section{ACKNOWLEDGMENTS}

The work was supported by the "Scientific and Technical Research Council of Turkey" (Grant No. 216Z105). The author thanks to Professor Zeynel Kılıç for his helpful discussions in spectroscopy. 


\section{REFERENCES}

1. Chandrasekhar V, Narayanan RS. Phosphazenes. Organophosphorus Chem. 2017 Mar; 46 : 342-417, Royal Sciety of Chemistry (RSC Publishing).

2. Stewart FF. Phosphazenes. Organophosphorus Chem. 2015 Apr; 44: 397-430, Royal Sciety of Chemistry (RSC Publishing).

3. Chandrasekhar V, Narayanan RS. Phosphazenes. Organophosphorus Chem. 2016 Mar; 45 : 375-437, Royal Sciety of Chemistry (RSC Publishing).

4. Medjdoub L, Mohammed B. New method for nucleophilic substitution on hexachlorocyclotriphosphazene by allyamine using an algerian proton exchanged montmorillonite clay (maghnite- $\mathrm{H}^{+}$) as a green solid catalyst. Bull. Chem. React. Eng.\&Catal. 2016 Aug; 11: 151160.

5. Egemen G, Hayvalı M, Kılıç Z, Solak AO, Üstündağ Z. Phosphorus-Nitrogen Compounds. Part 17. The Synthesis, Spectral and Electrochemical Investigations of Porphyrinophosphazenes. J. Porphyrins Phthalocyanines. 2010 Mar; 14: 227-234.

6. Okumuş A, Elmas G, Kılıç Z, Ramazanoğlu N, Açık L, Türk M, Akça G. The reactions of $\mathrm{N}_{3} \mathrm{P}_{3} \mathrm{Cl}_{6}$ with monodentate and bidentate ligands: The syntheses and structural characterizations, in vitro antimicrobial activities and DNA interactions of 4-fluorobenzyl(N/O)spirocyclotriphosphazenes. Turk. J. Chem. 2017 Mar; 41: 525-547.

7. Tümer Y, Asmafiliz N, Zeyrek CT, Kılıç Z, Açık L, Çelik SP, Türk M, Tunalı BÇ, Ünver H, Hökelek $T$, Syntheses, spectroscopic and crystallographic characterizations of cis- and trans-dispirocyclic ferrocenylphosphazenes: molecular dockings, cytotoxic and antimicrobial activities. New J. Chem. 2018 Jan; 42: 1740-1756.

8. Kılıç Z, Okumuş A, Demiriz Ş, Bilge S, Öztürk A, Çaylak N, Hökelek T. Phosphorus-nitrogen compounds: Part 16. Synthesis, stereogenism, anisochronism and the relationship between ${ }^{31} \mathrm{P}$ NMR spectral and crystallographic data of monotopic spiro-crypta phosphazene derivatives. J. Incl. Phenom. Macrocycl. Chem. 2009 Dec; 65: 269-286.

9. Okumuş A, Kılıç Z, Hökelek T, Dal H, Açık L, Öner Y, Koç L.Y. Phosphorus-nitrogen compounds part 22. syntheses, structural investigations, biological activities and DNA interactions of new mono and bis (4-fluorobenzyl)spirocyclophosphazenes. Polyhedron. 2011 Nov; 30: 2896-2907.

10. Tümer Y, Koç LY, Asmafliz N, Kılıç Z, Hökelek T, Soltanzade H, Açık L, Yola ML, Solak AO. Phosphorus-nitrogen compounds: part 30. syntheses and structural investigations, antimicrobial and cytotoxic activities and DNA interactions of vanillinato-substituted NN or NO spirocyclic monoferrocenyl cyclotriphosphazenes. J. Biol. Inorg. Chem. 2015 Dec; 20: 165-178.

11. Okumuş A, Akbaş H, Kılıç Z, Koç LY, Açık L, Aydın B, Türk M, Hökelek T, Dal H. Phosphorusnitrogen compounds: part 33: in vitro cytotoxic and antimicrobial activities, DNA interactions, syntheses and structural investigations of new mono(nitrobenzyl)cyclotriphosphazenes. Res. Chem. Intermed. 2016; 42: 4221-4251.

12. Jimenez J, Laguna A, Gascon E, Sanz JA, Serrano JL, Barbera J, Oriol L. New liquid crystalline materials based on two generations of dendronised cyclophosphazenes. Chem. Eur. J. 2012 Nov; 18: 16801-16814.

13. Omotowa BA, Phillips BS, Zabinski JS, Shreeve JM. Phosphazene- based ionic liquids: synthesis, temperature-dependent viscosity, and effect as additives in water lubrication of silicon nitride ceramics. Inorg. Chem. 2004 July; 43: 5466-5471.

14. Nishimoto T, Yasuda T, Lee S.Y, Kondo R, Adachi C. A six-carbazole-decorated cyclophosphazene as a host with high triplet energy to realize efficient delayed-fluorescence OLEDs. Mater. Horiz. 2014 Sep; 1: 264-269. 
15. Şenkuytu E, Eçik ET. Novel fully-BODIPY functionalized cyclotetraphosphazene photosensitizers having high singlet oxygen quantum yields. Spectrochim. Acta Part A, 2017 July; 182: $26-31$.

16. Coşut B. Highly efficient energy transfer in BODIPY-pyrene decorated cyclotriphosphazene. Dyes and Pigments, 2014 Jan; 100: 11-16.

17. Asmafiliz N, Kılıç Z, Civan M, Avcı O, Gönder LY, Açık L, Aydın B, Türk M, Hökelek T. Phosphorus-nitrogen compounds. Part 36. Syntheses, Langmuir-Blodgett thin films and biological activities of spiro-bino-spiro trimeric phosphazenes. New. J. Chem. 2016 Nov; 40: 9609-9626.

18. Elmas G, Okumuş A, Sevinç $P$, Kılıç Z, Açık L, Atalan M, Türk M, Deniz G, Hökelek T. Phosphorus-nitrogen compounds. Part 37. Syntheses and structural characterizations, biological activities of mono and bis(4-fluorobenzyl)spirocyclotetraphosphazenes. New J. Chem. 2017 May; 41 : 5818-5835.

19. Labarre JF, Faucher JP, Levy G, Sournies F, Cros S, François G. Antitumour activity of some cyclophosphazenes. Eur. J. Cancer, 1979 May; 15: 637-643.

20. Elmas G, Okumuş A, Kılıç Z, Çam M, Açık L, Hökelek T. Phosphorus-nitrogen compounds. Part 40. The syntheses of (4-fluorobenzyl) pendant armed cyclotetraphosphazene derivatives: Spectroscopic, crystallographic and stereogenic properties, DNA interactions and antimicrobial activities. Inorg. Chim. Acta. 2018 Jan; 476: 110-122.

21. Elmas G, Okumuş A, Kılıç Z, Çelik SP, Açık L. The spectroscopic and thermal properties, antibacterial and antifungal activity and DNA interactions of 4-(fluorobenzyl)spiro(N/O) cyclotriphosphazenium salts, J. Turk. Chem. Soc. Sect. A: Chem. 2017 Sep; 4 (3): 993-1016.

22. Mutlu G, Elmas G, Kılıç Z, Hökelek T, Koç LY, Türk M, Açık L, Aydın B, Dal H. Phosphorusnitrogen compounds: part 31. syntheses, structural and stereogenic properties, in vitro cytotoxic and antimicrobial activities, DNA interactions of novel bicyclotetraphosphazenes containing bulky side group. Inorg. Chim. Acta. 2015 July; 436: 69-81.

23. Akbaş H, Karadağ A, Aydın A, Destegül A, Kılıç Z. Synthesis, structural and thermal properties of hexapyrrolidinocyclotriphosphazenes-based protic molten salts: antiproliferative effects against HT29, HeLa, and C6 cancer cell lines. J. Mol. Liq. 2017 Jan; 230: 482-495.

24. Okumuş A, Elmas G, Cemaloğlu R, Aydın B, Binici A, Şimşek H, Açık L, Türk M, Güzel R, Kılıç $Z$, Hökelek T. Phosphorus-nitrogen compounds. part 35. syntheses, spectroscopic and electrochemical properties, antituberculosis, antimicrobial and cytotoxic activities of monoferrocenyl-spirocyclotetraphosphazenes. New J. Chem. 2016 Apr; 40: 5588-5603.

25. Sangshetti JN, Zambare AS, Kalam Khan FA, Gonjari I, Zaheer Z. Synthesis and biological activity of substituted 4,5,6,7-tetrahydrothieno pyridines: a review. Mini Rev. Med. Chem. $2014 ; 14$ (12): 988-1020.

26. Das RN, Chevret E, Desplat V, Rubio S, Mergny JL, Guillon J. Design, synthesis and biological evaluation of new substituted diquinolinyl-pyridine ligands as anticancer agents by targeting $\mathrm{g}$ quadruplex. Molecules, 2018 Dec; 23 (1): 81-95.

27. Bruker program 1D WIN-NMR (release 6.0) and 2D WIN-NMR (release 6.1).

28. Hongyan L, Lo JM, Fanwick PE, Stowell JG, Green MA. Monoprotic tetradentate N3O-donor ligands and their $\mathrm{Cu}(\mathrm{II})$ and $\mathrm{Ni}(\mathrm{II})$ complexes. Inorg. Chem. $1999 \mathrm{Apr}$; 38: 2071-2078.

29. Davidson RJ, Ainscough EW, Brodie AM, Harrison JA, Waterland MR. The Nature of the Phosphazene Nitrogen-Metal Bond: DFT Calculations on 2-(Pyridyloxy)cyclophosphazene Complexes. Eur. J. Inorg. Chem. 2010 March; 11: 1619-1625.

30. Elmas G, Okumuş A, Kılıç Z, Gönder LY, Açık L, Hökelek T. The Syntheses and Structural Characterizations, Antimicrobial Activity and in vitro DNA Binding of 4Fluorobenzylspiro(N/O)cyclotriphosphazenes and their Phosphazenium Salts. J. Turk. Chem. Soc. Sect. A: Chem. 2016 Aug; 3 (3): 25-46. 
31. Koçak SB, Koçoğlu S, Okumuş A, Kılıç Z, Öztürk A, Hökelek T, Öner Y, Açık L. Syntheses, spectroscopic properties, crystal structures, biological activities, and dna interactions of heterocyclic amine substituted spiro-ansa-spiro- and spiro-bino-spiro-phosphazenes. Inorg. Chim. Acta. 2013 Sep; 406: 160-70.

32. Elmas, G. The reactions of 2-trans-6-bis(4-fluorobenzyl)spirocyclotetraphosphazene with primary amines: spectroscopic and crystallographic characterizations. Phosphorus Sulfur Silicon Relat. Elem. 2017 Sep; 192 (11): 1224-1232.

33. Elmas G, Okumuş A, Cemaloğlu R, Kılıç Z, Çelik SP, Açık L, Tunalı BÇ, Türk M, Çerçi NA, Güzel $\mathrm{R}$, Hökelek T. Phosphorus-nitrogen compounds. part 38. Syntheses, characterizations, cytotoxic, antituberculosis and antimicrobial activities and DNA interactions of spirocyclotetraphosphazenes with bis-ferrocenyl pendant arms. J. Organometallic Chem. 2017 Dec; 853: 93-106. 